\title{
Silat: The curriculum of Seni Silat Malaysia
}

\author{
Mohamad Nizam Mohamed SHAPIE ${ }^{* 1,2}$, \& Mohd Shahiid ELIAS 2 \\ ${ }^{1}$ Faculty of Sports Science \& Recreation, Shah Alam, Selangor, Universiti Teknologi MARA (UiTM) \\ (Malaysia) \\ 2 Pertubuhan Seni Gayung Fatani Malaysia Association (Malaysia)
}
5th IMACSSS World Scientific Congress Abstracts, Rio Maior (Portugal), October 6-8
Section: Historical, sociological and philosophical issues of MA\&CS
Type: Oral communication

\section{Introduction}

The purpose this paper is to provide the review of silat curriculum based on the effective ancient roots Malay warfare. Silat is a form of martial art of the Malay race, who are inhabitants the southern part of the Asian continent, covering the Malay Archipelago from the Easter Island in the east to Madagascar Island in the west (Anuar, 2007). The word silat means a kind of sport or game, which consists of quick movements in attacking and defending (Anuar, 1987).

Silat olahraga is a sport that existed in the midst of development of thousands of silat schools in Archipelago (Anuar, 1993). Olahraga means the ability for a silat exponent to perform his silat techniques in combat with striking and defensive actions such as punching, kicking, throwing, catching, parrying and blocking and any skill related to silat techniques.

According to Anuar (1987), the knowledge of self-defence is especially concerned with methods of defending oneself from any attacks, be they through erosion, parrying, dodging and others, which may endanger his attacker. Here, the knowledge of Seni Silat (the arts of silat) not only to defend oneself from being attack but also to attack our opponent thus preventing him from causing harm to us. These attacks can be carried out with hands and legs such as punching, hitting, kicking and others. The attacks and defense must be well planned to achieve the maximum effect such that the opponent cannot proceed with his attack.

There are many silat systems being practiced in Malaysia, however Seni Gayung Fatani is the only styles to have truly originated from the Malay Peninsula (Ministry of Culture, Art and Heritage, 2002). It is an original system whose syllabus does not hold techniques taken from other martial art forms or other silat or pencak silat styles. Seni Gayung Fatani has been acknowledged as a Malaysian heritage martial art and its curriculum has become the basis for the Malaysian Seni Silat Curriculum (Seni Silat Malaysia) practised all over Malaysia today. The comprehensive curriculum used ensures clear and concise execution and teaching.

In Malaysia, Seni Silat (the art of silat) is one of the self-defence that has been categorized under cocurriculum activity for school uniform activity (Ministry of Education, 1997). In its curriculum, Seni Silat Malaysia teaches self-defence, seni (arts), techniques, combat and also trains exponents for Silat Olahraga. Thus, one does not only learn how to fend off attackers but how to face an attacker who knows how to fight back.

Fitness is also stressed for each exponent. A healthy body helps the exponent become stronger and achieve better results. Training is also provided for those interested in competing in Silat Olahraga, the competitive fighting sport of silat. Many techniques learnt are applied here which gives the student a better understanding of these techniques and their applications as well as conditioning the athlete's mind and body to combative situations. 


\section{What is silat?}

Silat is the type of self-defence originated from Malaysia. Silat is deeply entrenched in the traditions and culture of Malaysian civilization. Though, Silat has left its footprints in civilizations of many other Asian countries such as Indonesia, Singapore, Brunei and Philippines, but its association and involvement with Malaysian population and culture is remarkable and hence so highly acknowledged.

Silat is different from pencak silat. Silat is originated from Malaysia while pencak silat is from Indonesia. Pencak silat movements inspired by the animal movements such as monkey, snake, tiger and etc. (Maryono, 2000) while silat is based from geometrical line and human anatomy movements (Anuar, 1992).

\section{Seni Gayung Fatani}

Seni Gayung Fatani is the most prominent registered silat association in Malaysia. This silat association was founded in 1976, and was actively promotes silat until now. It already spread its wing to countries such as France, Austria, Switzerland, United Kingdom and United States.

Seni Gayung Fatani was the overall champion in the National Silat Championship in 1991, 1992, 1993 and 1995. This association participated in the presentation involving eleven types of the world's best self-defence in 15 German cities (Anuar, 2007). This school became the champion for two years successively for Best Performance Group in art of self-defence which was participated by 40 other countries from 14 types of the world's best art of self-defence under the International Martial Arts Games Committee (IMGC) organized by International Taekwondo Federation (ITF) in Pyongyang, North Korea, 2004. Seni Gayung Fatani was also a champion in the competition that organized by Kung Fu/ Wushu in Perugia, Italy, 2005 (Anuar, 2007).

Seni Gayung Fatani participated in 4th Workshop of Martial Arts in 2014, Dr Mohamad Nizam Mahamed Shapie 8 dan (Malaysia) demonstrated techniques of silat to martial arts practitioners in Rzeszow, Poland (Pewelec, et al., 2015). The performance by the Seni Gayung Fatani team also caused a lot of interest to the spectators including special performance by Dr Mohamad Nizam Mohamed Shapie (8th dan) and Mohd Shahiid Elias (8th dan) in the Martial Arts Gala at the World Congress, International Martial Arts and Combat Sports Scientific Society (IMACSSS) (Pewelec, et al., 2015). The association also was invited as a strategic partner in World Congress of Malay Heritage 2014 that was held in Matrade Exhibition \& Convention Centre, Kuala Lumpur on 28-29 October 2014 . In 2015, this silat school was nominated (top eight) as Best Sport Organization of the Year in Asia Sports Industry Awards, Makati, Manila, Philipines. Seni Gayung Fatani is the only martial arts organization that was nominated from 168 sports organization that short-listed in the awards presentation.

Using the systematic syllabus that recognized by the Malaysian government (Anuar, 2002), this school plays an important role to develop and spread silat all around the world. The Seni Gayung Fatani syllabus has been acknowledged as a national heritage and its curriculum has become the basis for the Malaysian Seni Silat Curriculum.

\section{Curriculum}

The Seni Silat Malaysia system for silat exponent consists of 7 different levels that can be identified and ranked using belt system starting from white, blue, brown, yellow, green, red and ending with black belt. Every silat topics will be majoring to 7 different topics such as:

- Bunga (the pillars of silat attacking and defensive positions)

- Jurus (the art of attack and defense either using weapon or bare hand )

- Belebat (the techniques of receiving strikes and how to counter it back )

- Tapak (the step pattern in silat movements) 
- Buah Pukul (the fast action of self-defence)

- Tempur Seni (the art of combat)

- Tempur Bela Diri (the speed and power movements of self-defence combat)

Every silat exponent will learn different style of attacking and defensive skill such as Elakan (avoiding technique movements), Tangkisan (blocking techniques), Tangkapan (catching techniques), Potong (counter-strike), Amuk (rampage with due diligent) and weaponry system such as sickle, sword, cudgel, kris or a short wavy dagger, rope, walking stick made of hardwood, dagger with straight cutting edge and trisula. The practical self-defence, unarmed self-defence and self-defence knife system also will be given in each silat level.

This will make every silat exponent ready to receive any strike either one on one or in group strikes as every level of the syllabus will explain how to handle every fighting situation just like in the war. As the silat curriculum is based from the art of war of Malay civilization from thousands of years ago, it is important to know that Silat Malaysia teach their students that prevention is better than cure. It is better to avoid a fight rather to get involved in it. In silat, it is prohibited to harm or kill others except in desperate situation where there is no other choice to defend yourself. Fighting is the last choice when there is no other solution to defend from being killed.

\section{Discussion and Conclusion}

The curriculum of Seni Silat Malaysia is the Malays heritage that upholds silat as the national selfdefense. It helps to provide the pathways to those who wanted to continue their career in martial art education services as well as the role of Malaysian socio-cultural. Uniformity of martial arts services will simplify the silat management to expand their knowledge to all coaches and administrators in order to empower the silat services all around the country. Malaysia should be proud with the legacy of this heritage (silat martial arts) that allows the formation of the silat curriculum that known as Kurikulum Seni Silat Malaysia (the curriculum of Seni Silat Malaysia). This martial arts curriculum is the evidence of the Malay's contribution to the world civilization.

\section{References}

Anuar, A.W. (1987). Silat Olahraga. Kuala Lumpur: Dewan Bahasa dan Pustaka.

Anuar, A.W. (1992). Teknik dalam Seni Silat Melayu (Technique in Malay Silat). Kuala Lumpur: Dewan Bahasa dan Pustaka.

Anuar, A.W. (1993). Silat Olahraga. The art, technique and regulations. (2nd ed.). Kuala Lumpur: Dewan Bahasa dan Pustaka.

Anuar, A.W. (2002). Pendidikandan Nilai-nilai Murnidalam Seni Silat (Education and Noble Values in Martial Arts). In Ministry of Culture, Art and Heritage, Manual jurulatih dan ringkasan mengajar (Instructor manual and summary of coaching), Tahap 1, SeniSilat Malaysia UntukJurulatih (First level, SeniSilat Malaysia for coaches). Paperwork. Kuala Lumpur: Ministry of Culture, Art and Heritage.

Anuar, A.W. (2007). Silat. Sejarah perkembangan kurikulum silat Melayu tradisi dan pembentukan kurikulum Silat Malaysia moden (Silat: The development history of traditional Malay silat and development of modern Silat Malaysia curriculum.). Bandar Baru Bangi, Selangor: Hizi Print Sdn Bhd.

Ministry of Education (1997). Surat pekeliling. Ikhtisas Bil. 2/1997: Pengiktirafan Persatuan Seni Bela Diri Sebagai Pasukan Pakaian Seragam Sekolah (Circulars. Professional Billing. 2/1997: Recognition for Martial Arts Society as School Uniforms Team). Shah Alam, Malaysia.

Ministy of Culture, Art and Tourism, (2002). Kertas Konsepdan Perlaksanaan; Fasa 1 Pengembangan Seni Silat Di Sekolah-sekolah (Concept Paper and Enforcement: Phase 1 Expansion of SeniSilat at Schools). In Manual Jurulatih dan Ringkasan Mengajar, Tahap 1, Seni Silat Malaysia Untuk Jurulatih (Trainers Manual and Summary of Teaching, Level 1, Seni Silat Malaysia for Trainers). Kuala Lumpur. 
Maryono, O’O. (2000). Pencak Silat Merentas Waktu (Pencak Silat Across Time). Bandung, Jakarta: PenerbitTarate.

Pewelec, P., Słopecki, J., Sieber, L. \& Rut, P. (2015). Scientific and martial arts' tourism. The case study of the 3rd IMACSSS International Conference and Congress. Ido Movement For Culture. Journal of Martial Arts Anthropology, 15(1), 46-56.

Key words: Martial arts; seni gayung fatani; combat; combat sports; syllabus; curriculum; coaching.

We would like to thank Grandmaster Aminuddin Anuar from Pertubuhan Seni Gayung Fatani Malaysia for his support in this study. Special thanks to Faculty of Sports Science and Recreation, Universiti Teknologi MARA, Shah Alam, Selangor (UiTM) for the support in this research. 